\title{
A Review Regarding the Biogas Production Through Anaerobic Digestion of Organic Waste
}

\author{
Gheorghe Voicu ${ }^{1, a^{*}}$, Mirela Dincă ${ }^{1, b}$, Gigel Paraschiv ${ }^{1, c}$ \\ and Georgiana Moiceanu ${ }^{1, d}$ \\ ${ }^{1}$ University Politehnica of Bucharest, 313 Splaiul Independentei, sector 6, Bucharest, postal code \\ 060042, D 103 Building, Romania \\ aghvoicu_2005@yahoo.com, bmirela_dilea@yahoo.com, cparaschiv2005@yahoo.com, \\ dmoiceanugeorgiana@yahoo.com
}

Keywords: anaerobic digestion, biogas, animal manure, biogas plant, biogas purification

\begin{abstract}
Globally, the pollution prevention goals transposed in the Kyoto Protocol, require sustainable solutions regarding the management of organic waste from both agricultural, and livestock farms. Biogas production by anaerobic digestion of organic wastes and residues provides a range of socio-economic benefits, but also environmental, thus contributing to monitoring the complex relationship between human health and the environment. The European Union policies regarding renewable energy systems (Europe 2020 Strategy - A strategy for smart, sustainable and inclusive growth and Green Paper „Towards a European strategy for the security of energy supply“), highlights that the production of renewable energy, reducing greenhouse gas emissions and a sustainable waste management, are essential for sustainable development in the future.

In this context, this paper will review aspects of biogas production by anaerobic digestion of organic waste, stages of anaerobic digestion process and concepts of biogas plants used in European countries.
\end{abstract}

\section{Introduction}

The worldwide reductions of conventional energy resources, as well as the restrictive legislation regarding the level of environmental pollution, have created premises for the identification and exploitation of new economic and clean energy sources. Following the trend imposed by the European Union, the proportion of renewable energy sources use should increase significantly. Also, many countries, particularly those in the region of S-E Europe, give an increasing importance of issues such as environmental protection, maintaining biodiversity and reducing greenhouse gas emissions, issues that have created premises for the exploitation of other sources for obtaining fuel.

Biomass is considered one of the basic renewable resources for the future that can be used in small and large scale. A definition for biomass adopted by E.U. legislation is: ,the biodegradable fraction of products, waste and residues from agriculture (including vegetal and animal substances), forestry and related industries, as well as the biodegradable fraction of industrial and municipal waste" [1]. Worldwide, biomass is considered a valuable source of alternative energy to fossil fuels, because its energy can be transformed into a variety of forms of energy, such as: heat, steam, electricity, hydrogen, biogas, as well as other fuels (biodiesel, ethanol and methanol) that are considered substitutes for fossil fuels in transport [2].

Among the fuels from vegetal biomass, biogas has a great importance and can successfully replace fossil fuels for obtaining electricity and heat, but, uses of biogas exist for years also in the field of transport [3].

Biogas production by anaerobic digestion process is considered to be the optimal treatment for manure, as well as of a wide variety of organic wastes suitable for this purpose, because these substrates are converted into renewable energy and organic fertilizer for agriculture. In the European 
Union countries, are produced annually more than 1500 million tons of manure from animals. Another agricultural substrate suitable for anaerobic digestion to obtain biogas is represented by energy crops, among which the most common are maize silos and energy grass crops [4 - 6].

The main components of biogas are the methane $\left(\mathrm{CH}_{4}\right)$ and carbon dioxide $\left(\mathrm{CO}_{2}\right)$, but can also contain, depending on the composition of the substrate, traces or significant amounts of unwanted contaminants such as hydrogen sulfide, ammonia, water vapor and siloxanes whose presence could cause corrosion. Therefore, biogas quality (purity and composition) is very important, and his purification represents a crucial final step of the overall process of production for its final application [7]. Methane is the only component of biogas that contributes to its calorific value. Thus, depending on the type of substrate used and depending on the operating conditions of the fermenter, biogas composition consists of $50-75 \% \mathrm{CH}_{4}$ and $25-50 \% \mathrm{CO}_{2}$, together with the above mentioned components. It has been shown that $1 \mathrm{~m}^{3}$ of raw biogas with a content of $60 \% \mathrm{CH}_{4}$ at standard temperature and pressure, has a calorific value of $21.5 \mathrm{MJ}$ (equivalent to $5.97 \mathrm{kWh}$ of electricity) compared to pure methane which has a calorific value of $35.8 \mathrm{MJ}$ (9.94 kWh electricity equivalent) [8].

The biogas energy will play an important role in achieving the ambitious targets approved in 2009 by the European Directive for energy from renewable sources [9], which stipulates that a percentage of $20 \%$ of final EU energy must be provided from renewable sources by the year 2020 .

This review includes a general discussion on biogas technology, biogas plants concepts and aspects regarding anaerobic digestion process.

\section{Basic principles of anaerobic digestion}

The process of anaerobic digestion represents a biochemical process, by which complex organic substrates (vegetal biomass, animal manure, organic waste, wastewater, sludges from sewage system) are degraded, in the absence of oxygen, to the stage of biogas and digested by various types of anaerobic bacteria [6].

\subsection{The anaerobic digestion process stages}

For the anaerobic digestion process, in order to convert organic matter into biogas, are required several different consortia of microorganisms with different roles, which translates to a series of metabolic steps, namely: hydrolysis (or liquefaction), acidogenesis, acetogenesis and methanogenesis (see Fig. 1) [10, 11].

In the first step, hydrolysis (liquefaction), is taking place conversion of complex organic matter consisting of protein, polysaccharide, carbohydrate and lipid, in soluble oligomers and monomers, such as: sugars, long-chain fatty acids, amino acids and glycerol [10]. The hydrolysis process of organic polymers is usually performed by extracellular enzymes called hydrolases, and they may be or may be not the step of rate slowing of their conversion in anaerobic conditions [12].

In the second stage, called acidogenesis, soluble compounds are fermented and converted by the acidogenic bacteria in a mixture of intermediates compounds, such as carbon dioxide $\left(\mathrm{CO}_{2}\right)$, hydrogen $\left(\mathrm{H}_{2}\right)$, alcohols and organic acids [10].

In the third stage, acetogenesis, organic acids are partially oxidized by acetogenic bacteria producing hydrogen and acetic acid. In this stage, there are two different mechanisms: acetogenic hydrogenation and acetogenic dehydrogenation. Generally, in the anaerobic digestion process, acetogenesis refers to acetogenic dehydrogenation and especially at anaerobic oxidation of short and long chain fatty acids $[10,12]$.

Finally, in the methanogenesis stage, both acetic acid and hydrogen represent the substrate for the formation of methanogenic bacteria. Thus, acetic acid and hydrogen are converted into biogas, which is primarily composed of methane $\left(\mathrm{CH}_{4}\right)$, carbon dioxide $\left(\mathrm{CO}_{2}\right)$ and hydrogen sulphide $\left(\mathrm{H}_{2} \mathrm{~S}\right)$ [10]. 


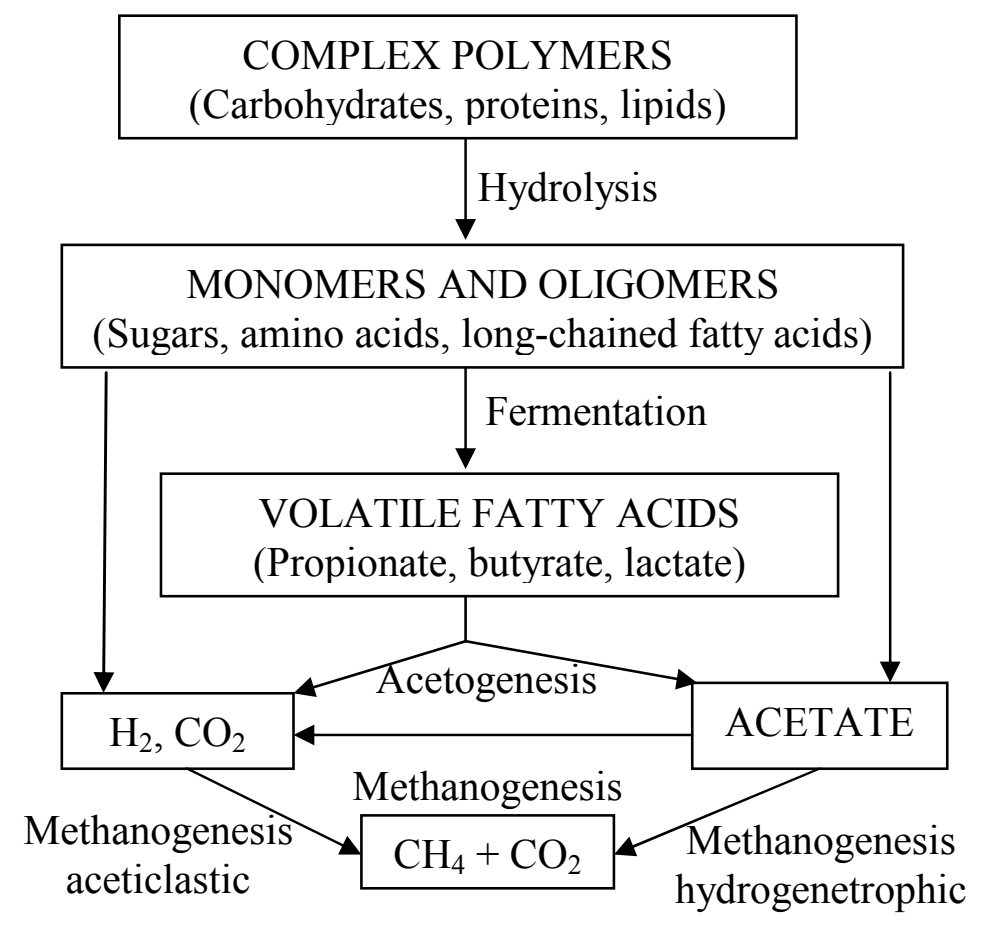

Fig. 1 The main stages of anaerobic digestion process $[10,11]$

\subsection{Parameters that influence the anaerobic digestion process}

Anaerobic microorganisms, especially especially the methanogenic one, are very sensitive to changes in environmental conditions. Many researchers [13-16] have studied the influence of some environmental factors that influence the anaerobic digestion process, because methanogenic bacteria are very vulnerable, and thus require careful monitoring of environmental conditions.

In this context, the most important parameters in the anaerobic digestion process which can completely inhibit the production of biogas are: the composition of the substrate, $\mathrm{C} / \mathrm{N}$ ratio, temperature, $\mathrm{pH}$, content of heavy metals, and homogenization of the substrate and retention time in the fermenter.

\subsection{Advantages of anaerobic digestion process}

Biogas production by anaerobic fermentation process and its use provides many socio-economic benefits, but also environmental, both to the whole society and for the farmers directly involved in this activity, such as [6]:

$\checkmark$ renewable energy source;

$\checkmark$ reduced emissions of greenhouse gases and reduce the global warming;

$\checkmark$ contribution to the alignment to the European Union requirements for energy and environmental protection;

$\checkmark$ reduction of biodegradable waste by turning them in the form of biogas and digestate (excellent fertilizer for agriculture);

$\checkmark$ reducing the odors from livestock but also from other organic waste;

$\checkmark$ significant additional source of income for the agricultural sector.

Anaerobic digestion has a limited impact on the environment, which is related to the biogas production itself [17]:

○ risk of odours, solved by burning odorous components in the exhaustion air or other odour treatment techniques

○ risk of explosion, solved by utilisation of explosion-proof equipment. 


\section{The situation of biogas technology in Romania vs. developed countries in Europe}

There are many types of biogas plants in Europe, categorised according to the type of digested substrates, according to the technology applied or according to their size. The biogas plants digesting manure are categorised as agricultural biogas plants, and they usually co-digest manure and other suitable organic residues, many of them of agricultural origin as well. The EU-countries where the agricultural biogas plants are most developed are Germany, Denmark, Austria and Sweden and to a certain level the Netherlands, France, Spain, Italy, United Kingdom and Belgium. The technology is under current development in countries like Portugal, Greece and Ireland as well as in many of the new, Eastern European, member states, where a large biomass potential is identified. One of the pioneer countries in developing agricultural biogas plants for manure and organic wastes co-digestion was Denmark, were the joint biogas plant concept was developed throughout the last two decades and represents today an integrated system of manure and organic waste treatment, nutrient recycling and renewable energy production, generating agricultural and environmental benefits [18].

According to IEA Bioenergy Task 37, [19], worldwide there are more than 340 biogas plants modernized. In Fig. 2 it can be seen that most modern biogas plants are found in Sweden and Germany.

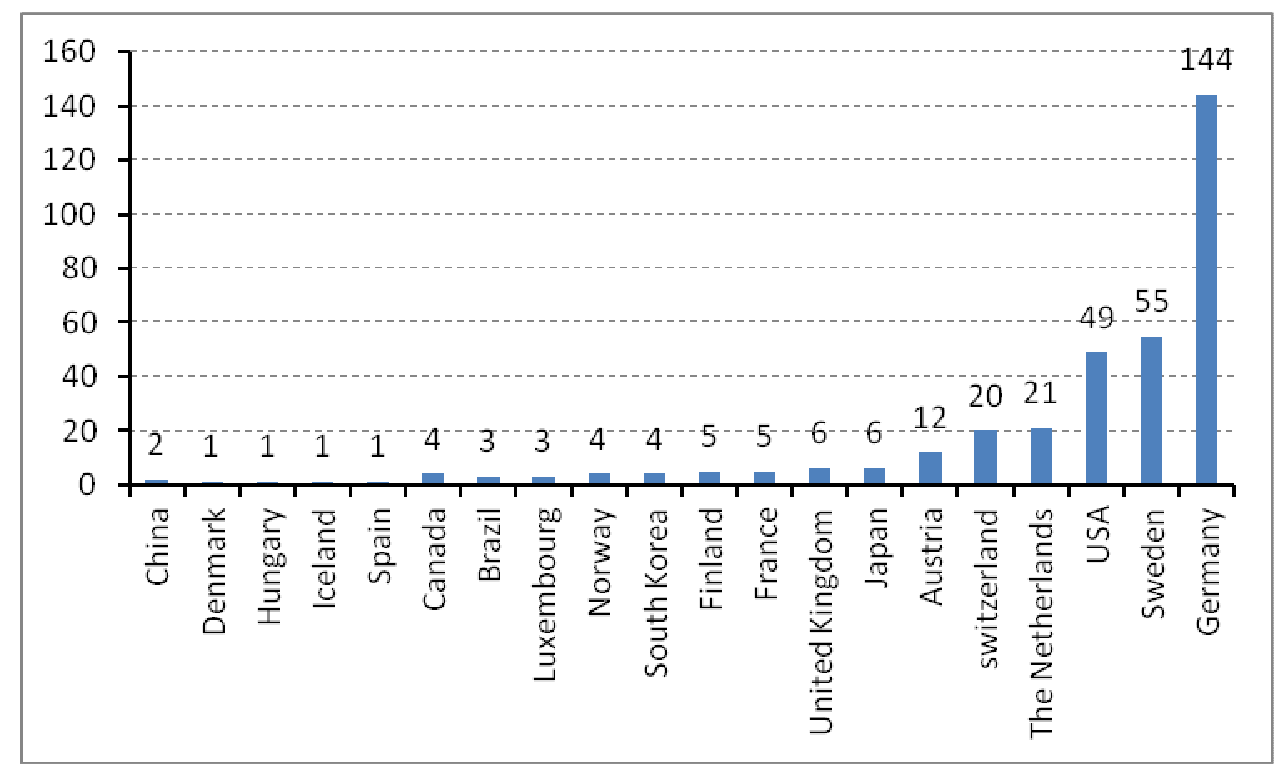

Fig. 2 Geographic location of modern biogas plants, reported by IEA Bioenergy Task 37 [19]

Biogas production in Europe shows a significant increase in the last period. According to the latest available data, it reached 8.3 million $t$ of oil equivalent in 2009 , fact which represents an increase of $4.3 \%$ compared to 2008 . This increase is mainly due to the processing sector of methane from corn, which has developed in Germany in 2004. Germans are leaders in this sector, representing $51 \%$ of European biogas production, followed by Italy, the Czech Republic and Austria [20].

In Romania, the biogas technology sector is in its infancy, the biogas market in our country being one of the least developed in Europe. The biomass from agriculture can be an important source of raw material for biogas production. From this point of view, Romania has a utilized agricultural area of 13.9 million hectares, representing about $60 \%$ of the total area of the country, on this surface being distributed more than 4.3 million farms. 
It should be taken into account that the location of a biogas plant requires on the one hand the availability of raw materials used, but must be considered also the technical possibilities of supply, collection and transportation costs [6].

Prioritizing biomass sector, the Romanian Government is preparing the stage for sustainable and solid development of biomass and biogas, avoiding the problems of the past. Among the new projects of the biogas plants in Romania, include biogas plant from Ardud, Satu Mare, biogas plant from Prahova that processes an amount of 49 tons of organic substrates derived from Cris Tim sausage factory, biogas station in Tufeni, Olt County with a capacity of $800 \mathrm{~kW}$ which processes the substrate consisting of pig manure and maize silage or other vegetal wastes [21, 22].

Another important project regarding biogas technology in Romania is construction of the pilot plant for biogas production in Seini, Maramures County. The raw material that will be used will consist of waste from pigs, cows and chickens and silage produced from energy crops (corn or sorghum). Also, in the biogas plant will be used manure collected from households. The maximum capacity of biogas plant is 54.79 tons/day, namely 49.31 tons/day manure and 5.48 tons/day plant silage. The amount of biogas produced annually is estimated at $1.527 .445 \mathrm{~m}^{3} /$ year, its valorization leading to a production of about 2.923 million $\mathrm{kWh} /$ year of produced electricity [23].

Other biogas plants are found in Vaslui (plant loaded with poultry manure and with energy plants, which provides $340 \mathrm{~kW}$ and can reach a capacity of $500 \mathrm{~kW}$ ), Ialomita, Harghita i.e. [24].

Currently, in Romania, are produced about 1,700 t of oil equivalent (toe) electricity and about 1.900 toe thermal energy generated from biogas/year [25].

\section{Concepts of biogas plants}

Biogas installations processing agricultural substrates are some of the most important applications of anaerobic digestion today [26]. A biogas plant is a complex installation, consisting of a variety of elements. Depending on the type, size and operational conditions of each biogas plant, various technologies for conditioning, storage and utilisation of biogas are possible to implement. The biogas plants have a common principle layout: manure is collected in a pre-storage tank, close to the digester and pumped into the digester, which is a gas-tight tank, made of steel or concrete, insulated to maintain a constant process temperature. Digesters can be or vertical, usually with stirring systems, responsible for mixing and homogenising the substrate, and minimising risks of swimming-layers and sediment formation or horizontal. Apart from the digester, equipped with stirring system, the plant can include pre-storage for fresh biomass, storage for digested biomass and for biogas, and even a CHP unit [6].

When designing a fermenter suitable for a biogas plant must consider a number of factors including: the type of waste to be processed, the quantity of waste generated, and the local environmental conditions [27].

The Oregon State Department of Energy [28] reported that there are three basic digester designs: ,a covered lagoon digester" is suitable for liquid manure with less than $3 \%$ solids; ,,a complete mix digester" is suitable for manure having solids concentration of 3-10\%; and ,plug-flow digesters” are suitable for ruminant animal manure having solid concentrations of $11-13 \%$ ".

In Fig. 3 is represented the scheme of a horizontal fermenter used in Germany, with a capacity that can vary between $50-150 \mathrm{~m}^{3}$ [29].

Various types of biogas storage facilities are available today. The simplest solution is the biogas storage established on top of digesters, using a gas tight membrane, which has also the function of digester cover (Fig. 4). For larger biogas plants, separate biogas storage facilities are established, either as stand-alone facility or included in storage buildings. The biogas storage facilities can be operated at low, medium or high pressure [6].

To allow the efficient use of biogas obtained through anaerobic digestion process, its purification units need to be modernized in order to eliminate a percentage as high of carbon dioxide, hydrogen sulfide and water vapor [30]. 


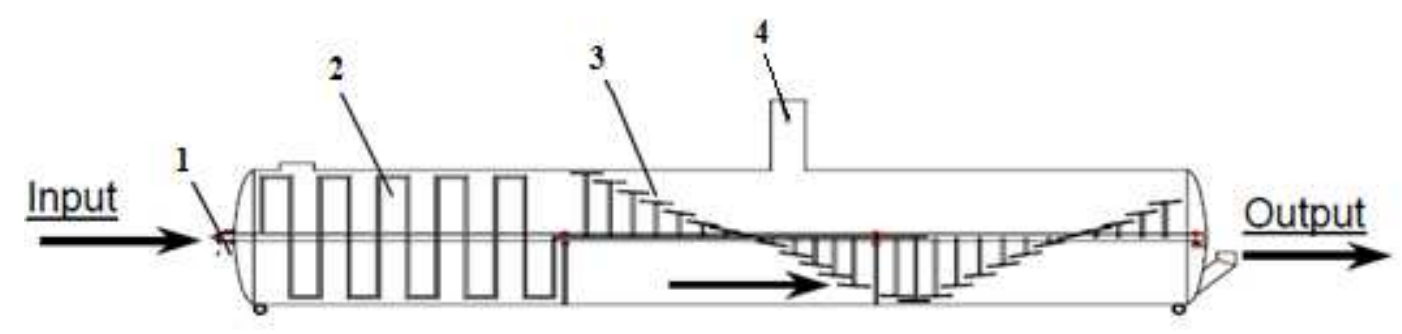

Fig. 3 Schematic representation of a horizontal fermenter used in Germany [29] 1 - motor, 2 - heating, 3 - mixer arms, 4 - gas dome

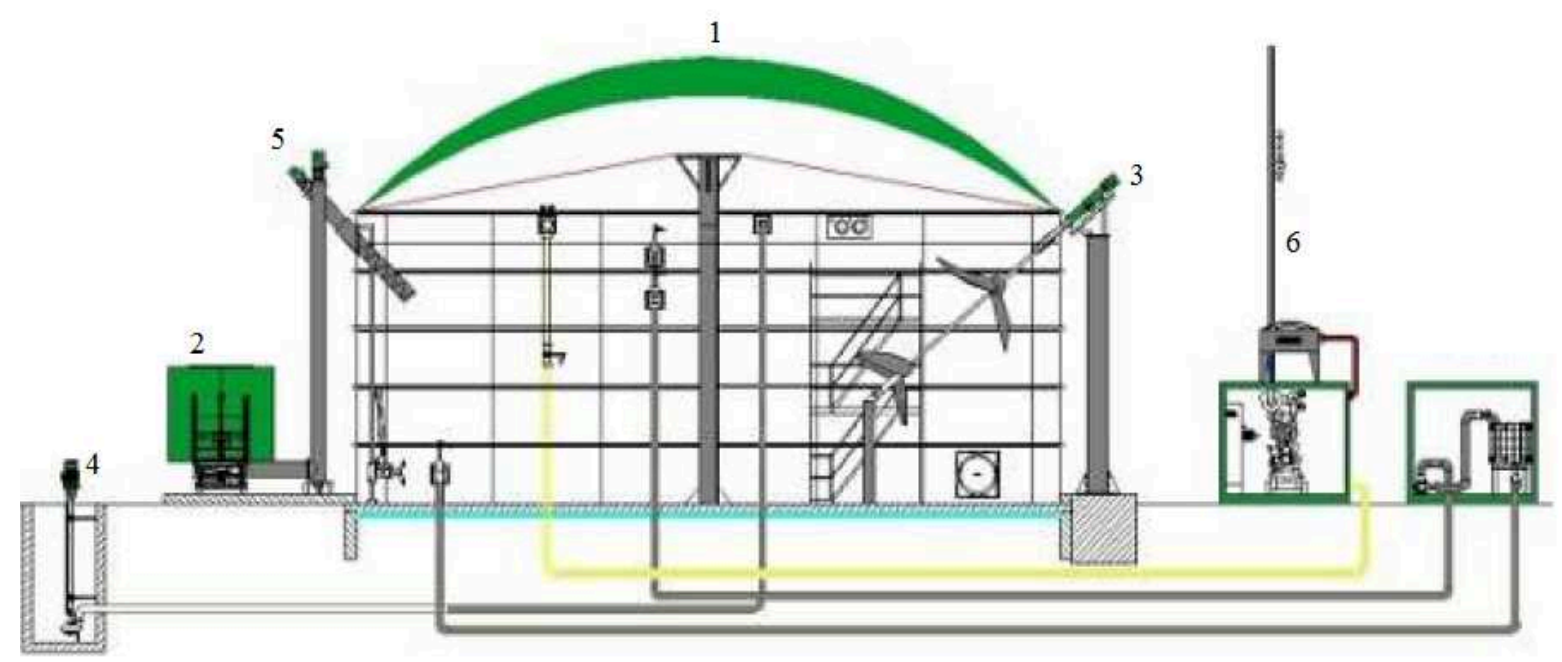

Fig. 4 Vertical digester covered with waterproof membrane for capturing biogas [23] 1 - digester; 2 - feeder; 3 - stirrer; 4 - liquid manure; 5 - conveyor; 6 - CHP unit

In the current biogas industry, absorption of carbon dioxide $\left(\mathrm{CO}_{2}\right)$ and hydrogen sulfide $\left(\mathrm{H}_{2} \mathrm{~S}\right)$ is performed using a water solution of amine. The most used amines for this purpose are methyldiethanolamine (MDEA), diethnolamine (DEA) and monoethanolamine (MEA) [31]. The diagram for $\mathrm{CO}_{2}$ and $\mathrm{H}_{2} \mathrm{~S}$ removal from biogas is shown in Fig. 5.

Another method for removing $\mathrm{CO}_{2}, \mathrm{H}_{2} \mathrm{~S}$ and water vapors from the biogas is to use a separation membrane (Fig. 6). During the purification process, is retained most of the $\mathrm{CH}_{4}$ percentage in the biogas, while carbon dioxide, hydrogen sulphide and water vapor permeate the membrane. The membranes used for purification of biogas are made of glassy polymer. The speed of diffusion through the membrane used in the biogas technology depends on the size of the molecules, and the degree of hydrophilicity [30,32].

As seen in the Fig. 5, the inlet stream (1), enters the absorber from the bottom, in which it is contacted with the amine solution (2). The $\mathrm{CO}_{2}\left(\right.$ and $\left.\mathrm{H}_{2} \mathrm{~S}\right)$ part of the biogas is reacted with the amine and transferred from the gas to the liquid phase. This is an exothermic reaction, heating the solution from the inlet $20-40^{\circ} \mathrm{C}$ to $45-65^{\circ} \mathrm{C}$. The product stream (3) exits in the top and contains mainly methane. The liquid exiting the absorber (4) is preheated using the stripper exit stream (14). The liquid is then passed to the top of the stripper column (5). Inside the stripper column, the liquid enters a flash box where any $\mathrm{CO}_{2}$ is removed. The liquid is then distributed and passed through a packing material where it is contacted with steam and $\mathrm{CO}_{2}$ released further down in the stripper column. 


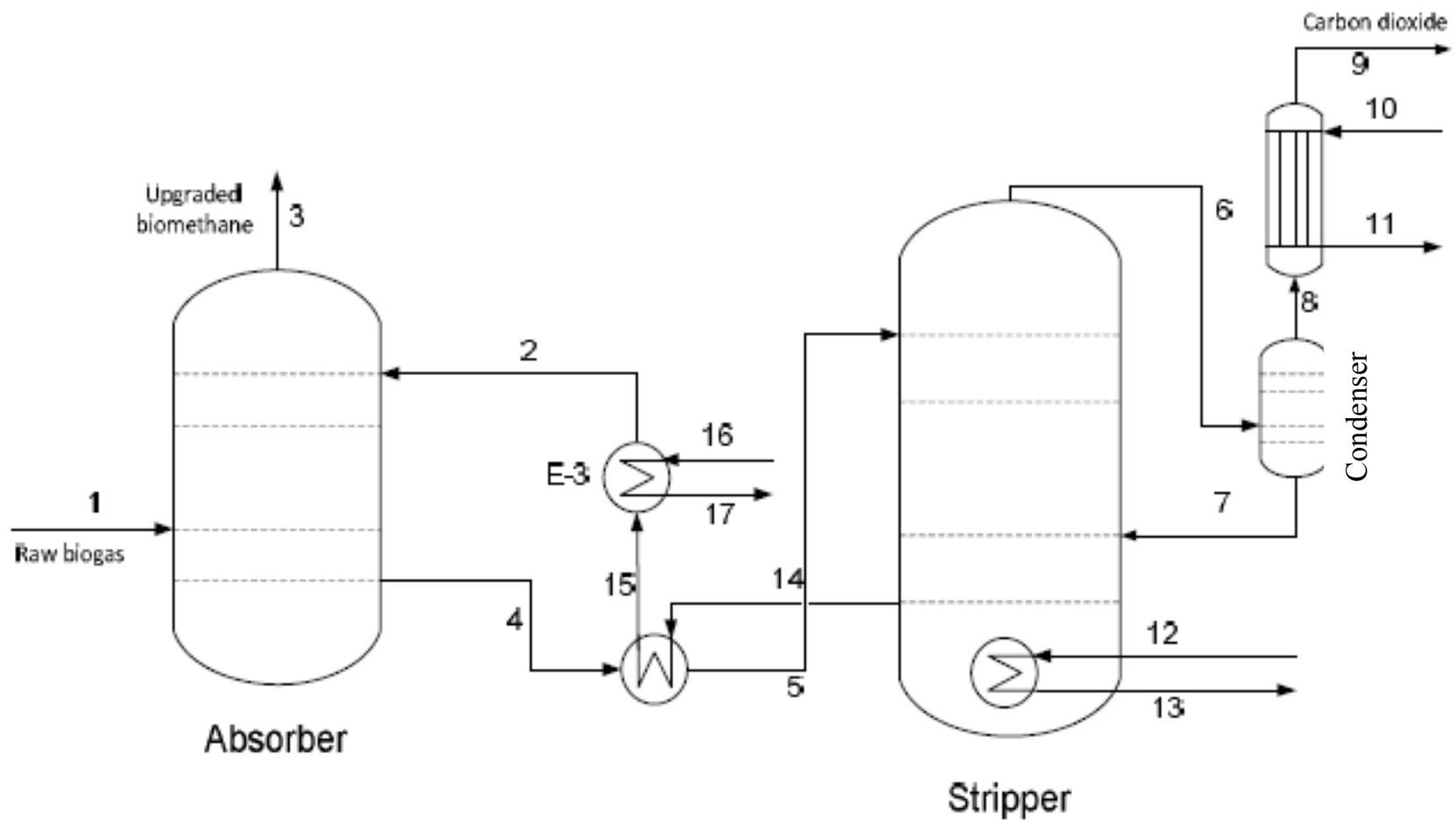

Fig. 5 The diagram of amine scrubber to remove $\mathrm{CO}_{2}$ and $\mathrm{H}_{2} \mathrm{~S}$ from biogas [30]

The bottom part of the stripper column is equipped with a reboiler in which heat is added (120$150^{\circ} \mathrm{C}$ ) and part of the amine solution boiled. The purpose of the reboiler is: first of all it provides the required heat of reaction for the release of $\mathrm{CO}_{2}\left(\right.$ and $\left.\mathrm{H}_{2} \mathrm{~S}\right)$ from the amine, secondly it generates steam to lower the partial pressure of the $\mathrm{CO}_{2}$ in the column which improves the kinetics of the desorption. The stripper pressure is slightly higher than the absorber pressure, usually $1.5-3$ bar. The heat supplied to the reboiler (12) may be hot water/oil or steam. The mixture of the released $\mathrm{CO}_{2}$ (and $\mathrm{H}_{2} \mathrm{~S}$ ) and steam exit the stripper column in the top (6) and is cooled in a condenser. The condensate (mainly steam but with traces of amine) is returned to the stripper (7). The cooled gas stream will consist mainly of $\mathrm{CO}_{2}$ and if $\mathrm{H}_{2} \mathrm{~S}$ is entered into the system it will leave it here.

The product gas will also have to be dried before being used in an automotive or indeed any other application. This is done using temperature swing adsorption, pressure swing adsorption or freeze drying [30].

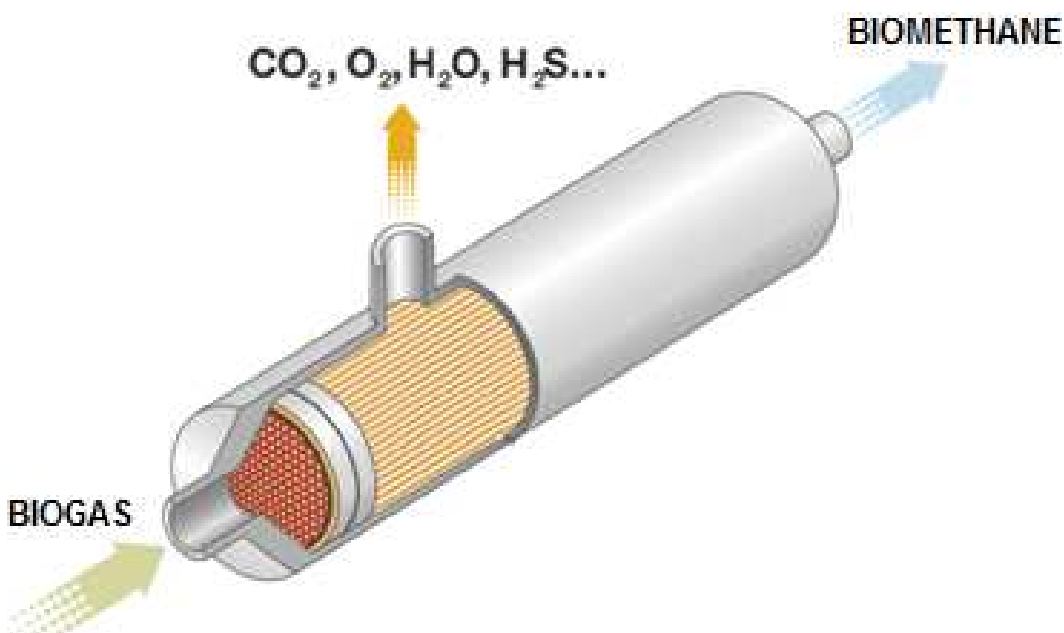

Fig. 6 Biogas purification using membrane technology [30, 33] 


\section{Conclusions}

Anaerobic digestion process of animal manure offers several environmental, agricultural and socio- economic benefits throughout improved fertilizer quality of manure, considerable reduction of odors and inactivation of pathogens and last but not least production of biogas production, as clean, renewable fuel, for multiple utilizations.

European directives relating to the renewable energy production, the reduction of greenhouse gas emissions and sustainable waste management is based on the commitment of Member States to implement appropriate measures to reach them. Biogas production from anaerobic digestion process and its use has the potential to meet all three targets simultaneously.

The concern for environmental risks reduction, sustainable development and use of renewable energy sources, have gained important valences in recent years, fact that led to adopt significant measures in our country, among which is found the process of anaerobic digestion.

The future development of biogas from manure co-digestion includes the use of new feedstock types such as by-products from food processing industries, bio-slurries from biofuels processing industries as well as the biological degradation of toxic organic wastes from pharmaceutical industries.

\section{Acknowledgement}

The work has been funded by the Sectorial Operational Programme Human Resources Development 2007-2013 of the Ministry of European Funds through the Financial Agreement POSDRU/159/1.5/S/134398.

\section{References}

[1] European Commission - EUR 21350, Biomass - Green energy for Europe, Luxembourg: Office for Official Publications of the European Communities 2005, ISBN 92-894-8466-7.

[2] B. Antizan-Ladislao, J.L. Turrion-Gomez, Second-generation biofuels and local bioenergy systems, Biofuels, Bioprod. Bioref. 2 (2008) 455-469.

[3] C. Mateescu, I. Constantinescu, Increasing the efficiency of biogas plants by improving the methane potential of vegetal biomass, Symposium of The impact of Acquis Communitaire on the equipment and environmental technologies, Agigea, 26-28th of August 2009.

[4] R. Braun, P. Weiland, A. Wellinger, Biogas from energy crop digestion, IEA Bionergy Task 37 - Energy from Biogas and Landfill Gas (2008).

[5] H. Menzi, Manure management in Europe: results of a recent survey, In: Proceedings of the 10th Conference of the FAO/ESCORENA Network on Recycling Agricultural, Municipal and Industrial Residues in Agriculture (RAMIRAN), 14-18 May, Strbske Pleso, Slovak Republic (2002) 93-102.

[6] T. Al Seadi, D. Rutz, H. Prass1, M. Köttner, T. Finsterwalder, S. Volk, R. Janssen, Biogas Handbook, University of Southern Denmark (2008) 7-19.

[7] A. Converti, R.P.S. Oliveira, B.R. Torres, A. Lodi, M. Zilli, Biogas production and valorization by means of a two-step biological process, Bioresource Technology 100 (2009) 5771-5776.

[8] K.C. Surendra, D. Takara, A. G. Hashimoto, S. K. Khanal, Biogas as a sustainable energy source for developing countries: Opportunities and challenges, Renewable and Sustainable Energy Reviews 31 (2014) 846-859.

[9] Directive 2009/28/EC of the European Parliament and of the Council of 23 April 2009 on the promotion of the use of energy from renewable sources and amending and subsequently repealing Dir. 2001/77/EC and 2003/30/EC, Official Journal of the European Union L 140/16 (2009) 16-47. 
[10] S.K. Khanal, Anaerobic biotechnology for bioenergy production: principles and applications, United States: John Wiley \& Sons, Inc. 2008.

[11] B. K. Ahring, Perspectives for Anaerobic Digestion, Advances in Biochemical Engineering/Biotechnology 81 (2003) 1 - 30.

[12] H. N. Gavala, I. Angelidaki, B. K. Ahring, Kinetics and Modeling of Anaerobic Digestion Process, Advances in Biochemical Engineering/ Biotechnology 81 (2003) 57- 93.

[13] K.J. Chae, A. Jang, S.K. Yim, I. S. Kim, The effects of digestion temperature and temperature shock on the biogas yields from the mesophilic anaerobic digestion of swine manure, Bioresource Technology 99 (2008) 1-6.

[14] H. Pobeheim, B. Munk, J. Johansson, G. M. Guebitz, Influence of trace elements on methane formation from a synthetic model substrate for maize silage, Bioresource Technology 101 (2010) 836-839.

[15] M. Aresta, M. Narracci, I. Tommasi, Influence of iron, nickel and cobalt on biogas production during the anaerobic fermentation of fresh residual biomass, Chemistry and Ecology, 19 (6) (2003) $451-459$.

[16] S. Ghanimeh, M. El Fadel, P. Saikaly, Mixing effect on thermophilic anaerobic digestion of source-sorted organic fraction of municipal solid waste, Bioresource Technology 117 (2012) 63-71.

[17] T. Al Seadi, Good practice in quality management of AD residues from biogas production, Report made for the Int. Energy Agency, Task 24 - Energy from Biological Conversion of Organic Waste. Published by IEA Bioenergy and AEA Technology Environment, Oxfordshire, UK, 2001.

[18] J.B. Holm-Nielsen, T. Al Seadi, P. Oleskowicz-Popiel, The future of anaerobic digestion and biogas utilization, Bioresource Technology 100 (2009) 5478-5484.

[19] IEA Bioenergy Task 37, Upgrading plant list 2013. Available at: http://www.ieabiogas.net/plant-list.html.

[20] Information on http://www.agro-business.ro

[21] Information on http://www.ecomagazin.ro

[22] Information on http://www.energyreport.ro

[23] I. Popescu, Instalație pilot pentru producerea biogazului Oraș Seini, județul Maramureș Raportul privind impactul asupra mediului, 2013.

[24] Information on http://agrointel.ro

[25] http://www.renexpo-bucharest.com

[26] EBA - European Biogas Association, Biogas- simply the best, Renewable Energy House, Brussels, Belgium, (2011).

[27] A. Hilkiah Igoni, M.J. Ayotamuno, C.L. Eze, S.O.T. Ogaji, S.D. Probert, Designs of anaerobic digesters for producing biogas from municipal solid-waste, Applied Energy 85 (2008) 430-438.

[28] Information on http://www.oregon.gov/ENERGY/RENEW/Biomass/Pages/Biogas.aspx

[29] T. Fischer, A. Krieg, Planning and construction of biogas plants, Krieg\&Fischer Ingenieure $\mathrm{GmbH}$, Germany.

[30] C. Hulteberg, F. Bauer, T. Persson, D. Tamm, Biogas upgrading - Review of commercial technologies, Swedish Gas Technology Centre, SGC Rapport 2013:270, available on http://www.sgc.se

[31] A. Kohl and R. Nielsen, Gas Purification, 5th Ed., Gulf Publishing Company, 1997, 734.

[32] R. W. Baker, Membrane Technology and applications, sec. Ed., John Wiley \& Sons Ltd, 2004.

[33] Information on http://www.airliquideadvancedtechnologies.com. 